University of Nebraska - Lincoln

DigitalCommons@University of Nebraska - Lincoln

$9-18-2018$

\title{
Acarine Biodiversity in Ecuador: Two New Species of Endoparasitic Chiggers (Acarina: Trombiculidae) from Terrestrial Andean Anurans
}

\author{
Ricardo Guerrero \\ Universidad Central de Venezuela, ricardo.guerrero.ucv@gmail.com \\ Mario Humberto Yánez-Muñoz \\ Instituto Nacional de Biodiversidad, Quito, Ecuador, mario.yanez@ambiente.gob.ec
}

Follow this and additional works at: https://digitalcommons.unl.edu/manter

Part of the Biodiversity Commons, Entomology Commons, Parasitology Commons, and the Zoology

Commons

Guerrero, Ricardo and Yánez-Muñoz, Mario Humberto, "Acarine Biodiversity in Ecuador: Two New Species of Endoparasitic Chiggers (Acarina: Trombiculidae) from Terrestrial Andean Anurans" (2018). MANTER: Journal of Parasite Biodiversity. 9.

https://digitalcommons.unl.edu/manter/9

This Article is brought to you for free and open access by the Parasitology, Harold W. Manter Laboratory of at DigitalCommons@University of Nebraska - Lincoln. It has been accepted for inclusion in MANTER: Journal of Parasite Biodiversity by an authorized administrator of DigitalCommons@University of Nebraska - Lincoln. 


\title{
Acarine Biodiversity in Ecuador: Two New Species of Endoparasitic Chiggers (Acarina: Trombiculidae) from Terrestrial Andean Anurans
}

\author{
Ricardo Guerrero ${ }^{1}$ and Mario Humberto Yánez-Muñoz ${ }^{2}$
}

1 Instituto de Zoología y Ecología Tropical, Facultad de Ciencias, Universidad Central de Venezuela, Caracas, Venezuela, ricardo.guerrero.ucv@gmail.com

2 Instituto Nacional de Biodiversidad, Quito, Ecuador, mario.yanez@ambiente.gob.ec

\begin{abstract}
Two species of endoparasitic chiggers, Vercammenia neotropica $\mathrm{n}$. sp. and Microtrombicula ecuadorensis n. sp., are described, both found in terrestrial anurans of the genus Pristimantis collected in the Andes of Ecuador. A new combination is proposed for Trombicula yorkei Sambon, 1928 as Microtrombicula yorkei (Sambon, 1928) n. comb., and Schoengastia lynni Ewing, 1942 is placed as incertae sedis. This is the first record of species of the genus Vercammenia in the Neotropical region.
\end{abstract}

Keywords: Vercammenia, Microtrombicula, Pristimantis, Ecuador

\section{Resumen}

Dos especies de ácaros endoparásitos, Vercammenia neotropica n. sp. y Microtrombicula ecuadorensis n. sp., son descritas, ambas encontradas en anuros terrestres del género Pristimantis recolectados en los Andes de Ecuador. Se propone una nueva combinación para Trombicula yorkei Sambon, 1928 como Microtrombicula yorkei (Sambon, 1928) n. comb., y Schoengastia lynni Ewing, 1942 se coloca como incertae sedis. Este es el primer descubrimiento de especies género Vercammenia en la Región Neotropical.

Palabras Claves: Vercammenia, Microtrombicula, Pristimantis, Ecuador

\section{Introduction}

The species of mites known from the family Trombiculidae number in the range of 2,500 to 3,000 (see Fernandes and Kulkarni, 2003; Gazêta et al., 2006; Stekolnikov and Daniel, 2012). These mites usually occur as ectoparasites mainly of mammals and birds, although some are parasites of frogs and toads (Krantz and Walter, 2009) and invertebrates
(Vercammen-Grandjean and Benoit, 1971), or endoparasites in vertebrates (Yunker and Jones, 1961; Brennan and Yunker 1966, 1969; Nadchatram, 2006). In frogs and toads, most known species are intradermal. Three genera have been described that include species of endoparasites from anurans: Hannemania Oudemans, 1911 in the New World, Endotrombicula Ewing, 1931 in Africa, and Vercammenia Audy and Nadchatram, 1957 in Southeast Asia and Australia. Two 
other species have been described from the neotropics, still with uncertain status: Vercammenia yorkei (Sambon, 1928) in Hyla rubra from Brazil and Schoengastia lynni Ewing,1942 "on frog" [sic] from Jamaica.

In a survey of frogs of the genus Pristimantis in the central and southern Andes of Ecuador, several specimens were found to be infected by intradermal chiggers (Trombiculidae); close examination of these mites showed two new species, and both are described in the next section.

\section{Material and Methods}

Frogs that were collected in the field were euthanized with $20 \%$ benzocaine, fixed in $10 \%$ formalin, and stored in $70 \%$ ethanol. Host vouchers were deposited at the herpetological collection of the Instituto Nacional de Biodiversidad (INABIO) in Ecuador.

Chiggers that were found in cysts or free under the skin were removed and preserved in $70^{\circ}$ ethanol, and some were mounted in Hoyer's medium on a microscope slide under a no. 1 cover slip. Measurements were taken with Nikon Labophot YF-21E microscope with Camera DS-Fi1 with Control Unit DS-L2 software; these are given in micrometers $(\mu \mathrm{m})$ as follows: holotype, mean with range of standard characters given in parentheses.

A camera lucida (drawing tube) was used to draw specimens; line drawings were edited with Adobe Photoshop CS6. Nomenclature of measured morphological structures and diagnostic formulas follow Goff et al. (1982) and Stekolnikov (2012). All type specimens have been deposited in the Colección de Acaros, Instituto Nacional de Biodiversidad (AC-INABIO) Quito, Ecuador and Colección de Parasitología, Museo de Biología, Universidad Central de Venezuela (CP-MBUCV), Caracas, Venezuela.

\section{Vercammenia neotropica $\mathrm{n} . \mathrm{sp}$.}

(Figs. 1, 3, 4, 5, 6; Tables 1, 2)

Diagnosis: SIF $=7 \mathrm{~B} . \mathrm{S}-\mathrm{N}-3-3111.0000 ; \mathrm{fPp}=\mathrm{B} / \mathrm{B} / \mathrm{NNB} ; \mathrm{PC}$ $=3 ; \mathrm{fCx}=1.1 .1 ; \mathrm{fSt}=2.2 ; \mathrm{fSC}=\mathrm{PL}>\mathrm{AL}=\mathrm{AM} ; \mathrm{fD}=2 \mathrm{H}-6-$ $6-4-2 ; \mathrm{fV}=2-2-2-4-2-4 \mathrm{u}-2 ; \mathrm{DS}=20 ; \mathrm{VS}=14 ; \mathrm{NDV}=34 ;$ $\mathrm{Ip}=620-707 ; \mathrm{H}=(40-53) ; \mathrm{D}_{\min }=(47-50) ; \mathrm{D}_{\max }=(50-56) ;$ $\mathrm{V}_{\min }=(31-45) ; \mathrm{V}_{\max }=(33-43) ; \mathrm{pa}=(217-254) ; \mathrm{pm}=(189$ 205); $\mathrm{pp}=(209-246)$.

Description (larvae $\mathbf{n}=\mathbf{1 7}$ ): Larvae in cysts embedded in the skin.

IDIOSOMA: 309, 397 (162-663) long and 224,293 (130520 ) wide. Eyes 2 pairs, eyes of each pair not in a common plate; anterior eye rounded and bigger, posterior lightly elongated in anterior-posterior axis and smaller. Humeral setae one pair, similar to other dorsal setae with short barb 46,48 (40-53) long. Dorsal setae decreasing in length posteriorly, anterior setae $52,53(50-56)$ and posterior 48,49 (47-50) long, fD 2H-6-6-4-2. Ventral side with 2-2 sternals similar in size and shape measuring the anterior pair 35,38 (33-43) and the posterior pair 40, 39 (31-45), caudal setae 52,47 (38-53), fV 2-2-2-4-2-4u-2. Total number of idiosomal setae excluding coxal 38 .

GNATHOSOMA: 67, 72 (59-80) long. Cheliceral blade with tricuspid cap wider in the base. Gnathobase with single pair of branched setae; galeala nude; palpal femur and genu with one branched seta; dorsal and lateral tibial setae nude and ventral seta branched; palpal tarsus with 7 branched setae, subterminala and tarsala; palpal claw with 3 prongs, one ventral and two dorsal.

SCUTUM: Rectangular, with rounded posterior margin, and punctuations connecting by thin horizontal lines; AM base at same level than ALs; sensillae far anterior to level

Table 1. Vercammenia neotropica n. sp. measurements of scutal and humeral setae of the type-series

\begin{tabular}{|c|c|c|c|c|c|c|c|c|c|c|c|}
\hline & AW & PW & SB & ASB & PSB & SD & $A P$ & AM & $A L$ & $\mathrm{PL}$ & $S$ \\
\hline Holotype & 67 & 71 & 31 & 26 & 32 & 58 & 34 & 32 & 29 & 58 & 68 \\
\hline Minimum & 53 & 55 & 29 & 20 & 23 & 47 & 30 & 27 & 29 & 51 & 40 \\
\hline Maximum & 72 & 76 & 35 & 29 & 36 & 62 & 41 & 38 & 44 & 63 & 68 \\
\hline Mean & 65 & 70 & 32 & 24 & 31 & 56 & 37 & 34 & 36 & 55 & 59 \\
\hline St. Dev. & 4.8 & 4.6 & 1.8 & 2.7 & 3.0 & 4.4 & 2.6 & 2.8 & 3.3 & 2.9 & 3.9 \\
\hline
\end{tabular}

Abbreviations: $\mathrm{AW}=$ distance between $\mathrm{ALS} ; \mathrm{PW}=$ distance between PLs; $\mathrm{SB}=$ distance between sensillary bases; $\mathrm{ASB}=$ distance from level of sensillary bases to extreme anterior margin of scutum; PSB = distance from level of sensillary bases to extreme posterior margin of scutum; $S D=$ length of scutum $(A S B+P S B) ; A P=$ distance from $A L$ to $P L$ on one side; $A M=$ length of tanteromedian setae; $\mathrm{AL}=$ length of anterolateral setae; $\mathrm{PL}=$ length of posterolateral setae; $\mathrm{S}=$ length of sensilla.

$(n=17)$ 

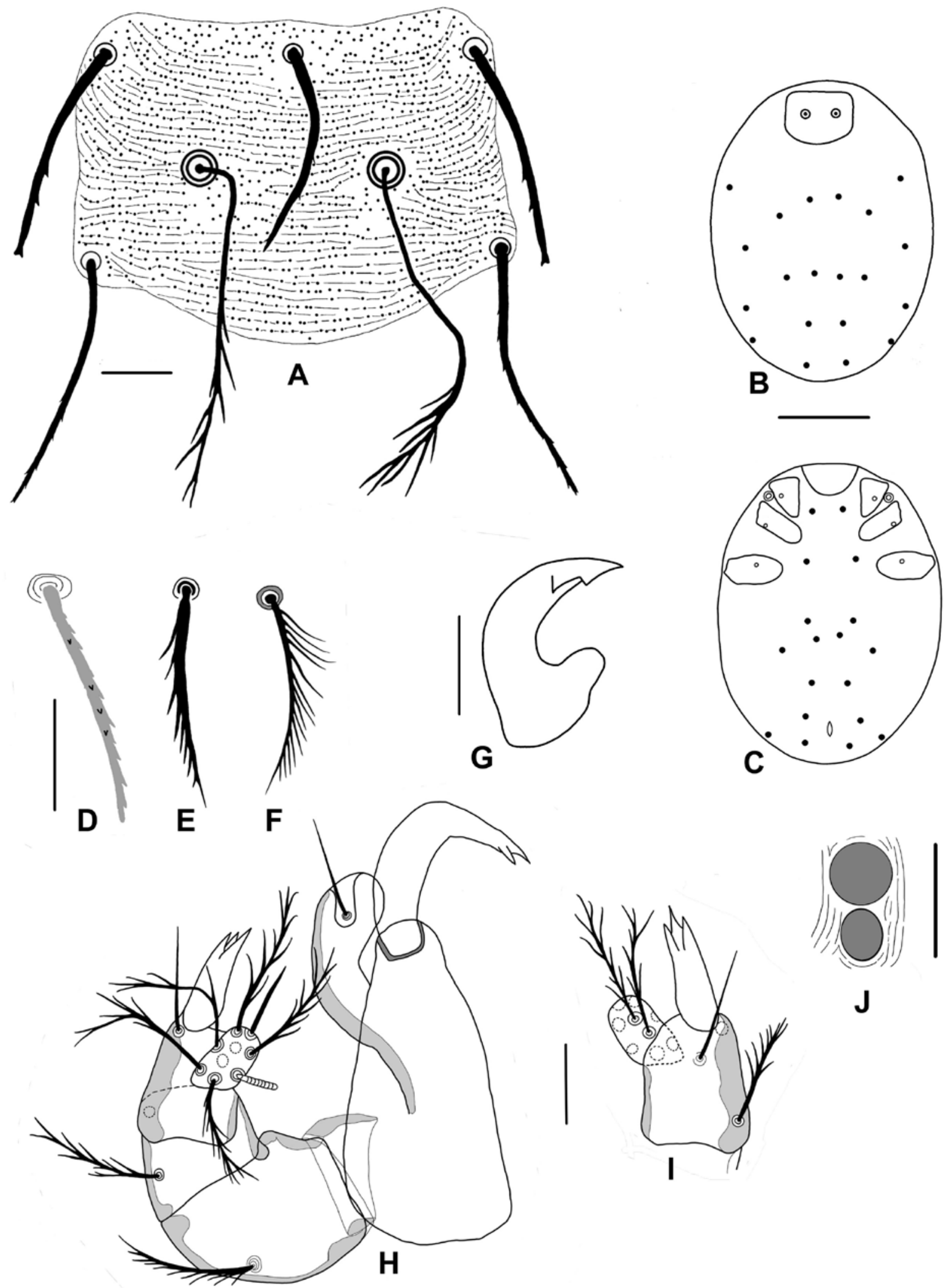

Figure 1. Vercammenia neotropica $\mathrm{n}$. sp. A, scutum; $B$, arrangement of dorsal idiosomal setae; $\mathrm{C}$, arrangement of ventral idiosomal setae; $D$, dorsal idiosomal seta; $E$, ventral idiosomal seta; $F$, sternal seta; $G$, cheliceral blade; $H$, gnathosoma, ventral view; I, palpal tibia and tarsus, dorsal view; J, eyes. Scale bars: $A, G, H, I=10 \mu m ; D, E, F, J=25 \mu m ; B, C=100 \mu \mathrm{m}$. 
Table 2. Vercammenia neotropica $\mathrm{n}$. sp. measurements of modified setae of the legs of the type-series

\begin{tabular}{|c|c|c|c|c|c|c|c|c|c|c|c|c|}
\hline & \multicolumn{5}{|c|}{ Tarsus } & \multicolumn{3}{|l|}{ Tibia } & \multicolumn{4}{|l|}{ Genu } \\
\hline & tar & pret & subt & paras & mcta & $\operatorname{tib} \varphi$ & tib & mcti & ge1 & ge2 & ge3 & $\mathrm{mcg}$ \\
\hline \multicolumn{13}{|l|}{ Leg I } \\
\hline Holotype & 23 & 15 & 23 & 24 & 2.8 & 20 & 25 & 3.6 & 21 & 21 & 21 & 3.1 \\
\hline Minimum & 18 & 14 & 21 & 13 & 2.5 & 19 & 22 & 3.0 & 17 & 18 & 20 & 2.9 \\
\hline Maximum & 23 & 22 & 26 & 24 & 3.2 & 23 & 32 & 4.7 & 25 & 25 & 23 & 4.0 \\
\hline Mean & 21 & 16 & 24 & 17 & 2.7 & 21 & 26 & 3.7 & 21 & 21 & 22 & 3.2 \\
\hline St. Dev. & 1.2 & 2.1 & 1.3 & 3.1 & 0.2 & 1.2 & 2.4 & 1.1 & 2.0 & 1.8 & 1.1 & 0.3 \\
\hline \multicolumn{13}{|l|}{ Leg ॥ } \\
\hline Holotype & 17 & 13 & & & 2.5 & 20 & 22 & & 21 & & & \\
\hline Minimum & 15 & 12 & & & 1.7 & 20 & 21 & & 19 & & & \\
\hline Maximum & 19 & 18 & & & 3.5 & 27 & 27 & & 24 & & & \\
\hline Mean & 17 & 13 & & & 2.7 & 22 & 23 & & 21 & & & \\
\hline St. Dev. & 0.9 & 1.6 & & & 0.5 & 1.8 & 1.5 & & 1.6 & & & \\
\hline \multicolumn{13}{|l|}{ Leg III } \\
\hline Holotype & & & & & & & 27 & & 21 & & & \\
\hline Minimum & & & & & & & 22 & & 19 & & & \\
\hline Maximum & & & & & & & 28 & & 24 & & & \\
\hline Mean & & & & & & & 25 & & 22 & & & \\
\hline St. Dev. & & & & & & & 1.7 & & 1.6 & & & \\
\hline
\end{tabular}

Abbreviations: $\operatorname{tar}=$ tarsala; pret $=$ pretarsala; subt $=$ subterminala; paras $=$ parasubterminala; $\mathrm{mcta}=$ microtarsala; $\operatorname{tib} \varphi=$ tibiala $\varphi$ (solenidion); tib = tibiala; $\mathrm{mcti}=$ microtibiala; ge1 =genuala $1 ;$ ge2 = genuala $2 ;$ ge 3 = genuala $3 ;$ mcg = microgenuala; Mtar = mastitarsala.

$(n=16)$

of PLs; PL > AL > AM (Table 1); scutal setae barbed similarly to dorsal setae; sensilla flagelliform with 7-8 long branches in distal half. Measurement of setae in table 1.

LEGS (Table 2): All 7-segmented, with the pair of claws and empodium. Leg I: 226, 233 (217-254) long; coxa 1B; trochanter $1 \mathrm{~B}$; basifemur $1 \mathrm{~B}$; telofemur $5 \mathrm{~B}$; genu $4 \mathrm{~B}$, 3 genualae, microgenuala; tibia $8 B, 2$ tibialae (1 solenidion), microtibiala; tarsus $18 \mathrm{~B}$, tarsala, microtarsala distal to tarsala, subterminala, parasubterminala with 1-2 small branches, pretarsala. Leg II: 196, 200 (189-205) long; coxa 1B; trochanter $1 \mathrm{~B}$; basifemur $2 \mathrm{~B}$; telofemur $4 \mathrm{~B}$; genu $3 \mathrm{~B}$, genuala; tibia 5B, 2 tibialae, microtibiala; tarsus $15 B$, tarsala, microtarsala proximal to tarsala, pretarsala. Leg III: 220, 226 (209246) long; coxa $1 \mathrm{~B}$; trochanter $1 \mathrm{~B}$; basifemur $2 \mathrm{~B}$; telofemur $3 \mathrm{~B}$; genu $3 \mathrm{~B}$, genuala; tibia $6 \mathrm{~B}$, tibiala; tarsus $15 \mathrm{~B}$.

Exemplars of three different idiosomal sizes were found. Idiosomal size is $162-663$, but they are morphologically identical and distributed randomly in infected frogs.

Type host: Pristimantis marcoreyesi Reyes-Puig, ReyesPuig, Ramirez-Jaramillo, Perez and Yánez-Muñoz, 2014 (Amphibia: Anura: Craugastoridae).
Type locality: Vertientes Orientales del Volcán Tungurahua, Cantón Baños, Provincia de Tungurahua, Ecuador (1 $\left.{ }^{\circ} 26^{\prime} 17.15^{\prime \prime S}, 78^{\circ} 25^{\prime} 0.53^{\prime \prime} \mathrm{W}\right), 2500 \mathrm{~m}$ (Fig. 6).

Type material: Holotype (AC-INB-0001), 10 paratypes (AC-INB-0002), and 6 paratypes (CP-MBUCV-6133), all from the same individual host. LSID urn:Isid:zoobank. org:act:FE09519E-B4F0-4BB1-AC66-CF9D3F238BCF

Etymology: The specific name refers to the zoogeographical region in which the host and parasites were found and described.

Remarks: The original diagnosis of Vercammenia by Audy and Nadchatram (1957) is: "larvae poorly sclerotized, with small (AW less than $50 \mu$ ) pentagonal scutum and five scutal setae, filiform nude sensilla, slender chelicers with few dorsal notches or denticles, and seven barbed setae on palpal tarsus; leg I with greatly elongate tarsala and three genualae; leg III with genuala and tibiala ..." and in the table of "Comparison of characters" point out "eyes: $2+2$ inconspicuous, posterior eye unsclerotized rudimentary." "Cheliceral blade: 2 notch-like teeth" and "Palpal tarsus: 7B" and 
in naked-eye characters: "chiggers in situ show them to be completely encysted immediately below the epidermis, with some flattening of epidermal cells."

Vercammen-Grandjean (1960), Domrow (1969), Domrow et al. (1983), and Domrow and Lester (1985) reviewed species in the genus and described some new species, showing the variability in the scutum and sensillae shape. The exemplars studied agree with description of the genus Vercammenia; six species have been assigned to it: $V$. hendricksoni Audy and Nadchatram, 1957 from Malaysia; V. gloriosa Domrow, 1969 and V. zweifelorum Domrow, Loomis and Lester, 1983, both from Australia; V. pringlei Vercammen-Grandjean and Langston, 1971 from South Africa; V. lynni (Ewing, 1942) from Jamaica; and V. yorkeri (Sambon, 1928) from Brasil. Domrow et al. (1983) don't recognize the species $V$. pringlei as belonging in the genus, and $V$. lynni and $V$. yorkeri are discussed below. The palpal formula (fPp), scutal ratio (PW/SD), and number of genualae I are: N.b.NBB.7B, 0.9, and 3 in V. hendricksoni; N.N.NNN.7B.S, 1.7, and 4 in V. gloriosa; b.b.bbB.7B.S, 1.3, and 3 in V. zweifelorum; and B.B.N.N.B.7B.S, 1.3, and 3 in $V$. neotropica $n$. sp. Our exemplars are closer to $V$. zweifelorum, but they differ in scutal shape, pentagonal deep (ratio PW/SD $=0.9$ ), and sensilla flagelliform in latter but the posterior scutal margin broadly rounded, shallow (ratio $\mathrm{PW} / \mathrm{SD}=1.17-1.25)$ and sensillae with few distal branched in the former.

All the chiggers were collected encysted below the epidermis.

Reyes-Puig et al. (2010) in the description of the host as a new species of frog, reported $42 \%$ of the type series with subcutaneous pouches in the axial region but erroneously identified the mites as belonging to the family Epidermoptidae.

This is the first record of the genus Vercammenia in the neotropics.

\section{Microtrombicula ecuadorensis $\mathrm{n}$. sp.}

(Figs. 2, 3, 6; Tables 3, 4)

Diagnosis: $\mathrm{SIF}=2 \mathrm{~N} 4 \mathrm{~B}-\mathrm{N}-2-3111.1000 ; \mathrm{fPp}=\mathrm{B} / \mathrm{B} / \mathrm{BNB} ; \mathrm{PC}$ $=2 ; \mathrm{fCX}=1.1 .1 ; \mathrm{fSt}=2.2 ; \mathrm{fSC}=\mathrm{PL}>\mathrm{AM}>\mathrm{AL} ; \mathrm{fD}=2 \mathrm{H}-6-$ 6-6-4-2; $\mathrm{fV}=2-2-4-6-2 \mathrm{u} 4-2 ; \mathrm{DS}=26 ; \mathrm{VS}=18 ; \mathrm{NDV}=44$; $\mathrm{Ip}=665-751 ; \mathrm{H}=(37-48) ; \mathrm{D}_{\min }=(32-36) ; \mathrm{D}_{\max }=(37-43) ;$ $\mathrm{V}_{\min }=(21-25) ; \mathrm{V}_{\max }=(26-31) ; \mathrm{pa}=(237-268) ; \mathrm{pm}=(191-$ 226); $\mathrm{pp}=(218-264)$.

Description (larvae $\mathbf{n}=16$ ): IDIOSOMA: 410, 463 (366$561)$ long and 251, 300 (212-398) wide. Eyes 1.0 the anterior in an elongated plate 23.4 (21.5-25.8) long. One pair of humeral setae 48, 41 (37-48) long and slightly more slender and longer than other dorsal setae; 20 dorsal setae moderately barbed and decreasing in size posteriad; 4 sternal setae, anterior pair thinner than posterior pair and with few thin branches and 18 ventral setae longer posteriad; total number of idiosomal setae, excluding coxalae, 48.

GNATHOSOMA: 45, 51 (44-59) long. Blade of chelicera with tricuspid cap bilobed at the base; gnathobase with single pair of 4 branched setae; galeala nude; palpal claw deeply bifurcate, with one ventral and one dorsal prong; setae on palpal femur and genu with 3-4 branches; dorsal and ventral tibial setae branched and lateral tibial seta nude; palpal tarsus with 1 nude and 1 nearly nude (sometimes with1 branch), 4 branched setae, and tarsala.

SCUTUM: Subpentagonal, rounded posterior margin, and with puncta randomly distributed; AM base very anterior to ALs; PL >AM > AL (Table 3); scutal setae barbed similarly to dorsal setae; sensillae flagelliform with 8-10 branches in distal half only in a side.

LEGS (Table 4): All 7-segmented, with the pair of claws and empodium. Leg I: 268, 255 (237-268) long; coxa 1B; trochanter $1 \mathrm{~B}$; basifemur $1 \mathrm{~B}$; telofemur $5 \mathrm{~B}$; genu $4 \mathrm{~B}$, 3 genualae, microgenuala; tibia $8 \mathrm{~B}, 2$ tibialae ( 1 is a solenidion, $\varphi)$, microtibiala; tarsus $22 \mathrm{~B}$, tarsala, microtarsala distal to tarsala, subterminala, thin and small parasubterminala, pretarsala. Leg II: 226, 214 (191-226) long; coxa 1N; trochanter1B; basifemur 2B; telofemur $4 \mathrm{~B}$; genu 3B, genuala; tibia $6 \mathrm{~B}, 2$ tibialae; tarsus $16 \mathrm{~B}$, tarsala, microtarsala proximal to tarsala, pretarsala. Leg III: 226, 246 (218-264); coxa 1B; trochanter 1B; basifemur2B; telofemur 3B; genu 3B, genuala; tibia $8 B$, tibiala; tarsus $13 B$, mastitarsala, nude or with 1 short branch.

Type host: Pristimantis aff. bellator after Yánez-Muñoz et al., 2013 (Amphibia: Anura: Craugastoridae).

Type locality: Reserva Biológica Tapichalaca, Zamora

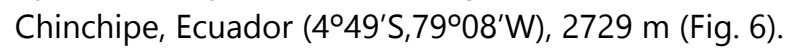

Type material: Holotype (AC-INB-0003), 9 paratypes (AC-INB-0004), and 6 paratypes (CP-MBUCV-6135) all from same individual host. LSID urn:Isid:zoobank. org:act:7E978016-9A7D-4FFE-B71E-A53285FB294D

Etymology: The specific name refers to the country of geographical origin, Ecuador.

Remarks: The exemplars belong to the genus Microtrombicula Ewing, 1950, and their characters agree with the definition in Webb and Loomis, 1970 as follows: "scutum subpentagonal, with 5 setae (1 AM seta) and without anteromedial projection; sensilla flagelliform nude or with few to many distal branches, or slightly expanded, ... 

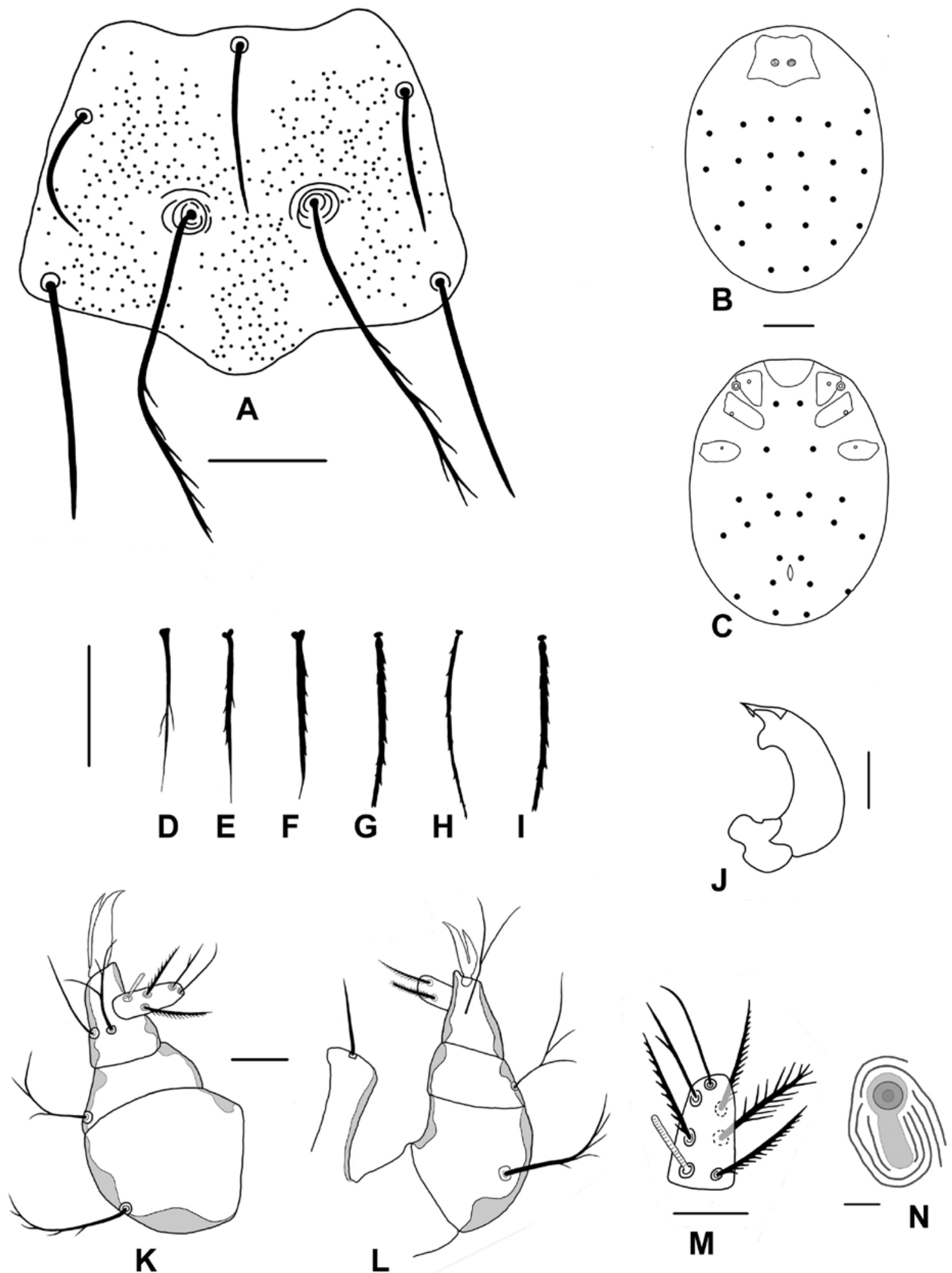

Figure 2. Microtrombicula ecuadorensis n. sp. A, scutum; $B$, arrangement of dorsal idiosomal setae; $C$, arrangement of ventral idiosomal setae; $D$, anterior sternal seta; $E$, posterior sternal seta; $F$, anterior idiosomal seta; $G$, posterior idiosomal seta; $H$, humeral seta; I, dorsal idiosomal seta; J, cheliceral blade; $K$, gnathosoma, ventral view; $L$, gnathosoma, dorsal view; $M$, palpal tarsus in ventral view; $N$, eye. Scale bars: J, K, L, M, N = $10 \mu \mathrm{m} ; A, D, E, F, G, H, I=25 \mu \mathrm{m} ; B, C=100 \mu \mathrm{m}$. 

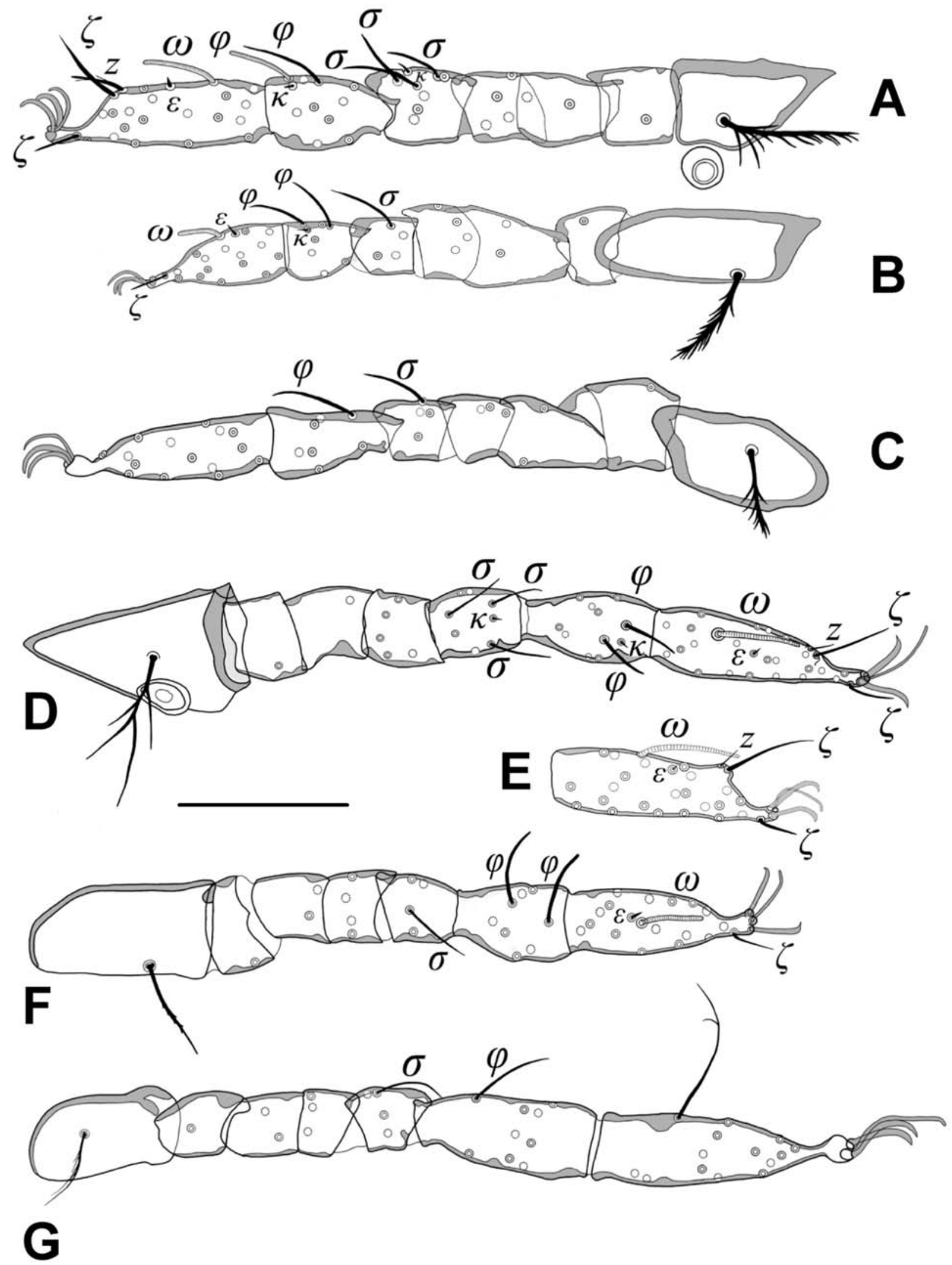

Figure 3. Vercammenia neotropica n. sp. A, Leg I; B, Leg II; C, Leg III. Microtrombicula ecuadorensis n. sp. D, Leg I; E, Tarsus I; F, Leg II; G, Leg III. Scale bar $=50 \mu \mathrm{m}$. 
palpotarsus with 6 branched and nude setae, tarsala and without subterminala; palpotibial claw trifurcate or bifurcate, cheliceral blade with tricuspid cap; 2-3 pairs of sternal setae; leg I with coxa unisetose .. . leg II with coxa usually unisetosa (rarely 2 setae) ..., leg III with coxa having 1-8 branched setae." Vercammen-Grandjean (1960) proposed the subgenus Scapuscutala for species of Microtrombicula

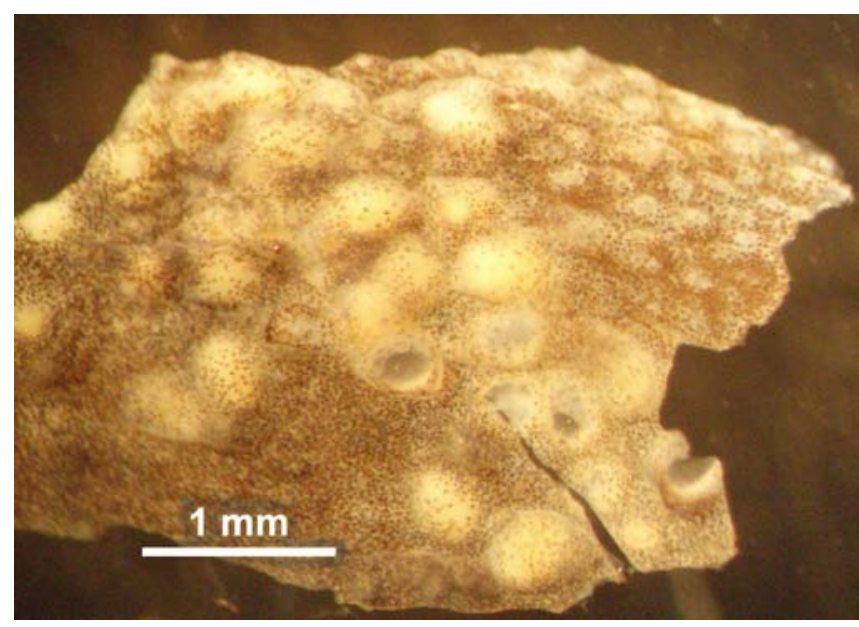

Figure 4. Skin of Pristimantis marcoreyesi showing nodules with Vercammenia neotropica $\mathrm{n}$. $\mathrm{sp}$.

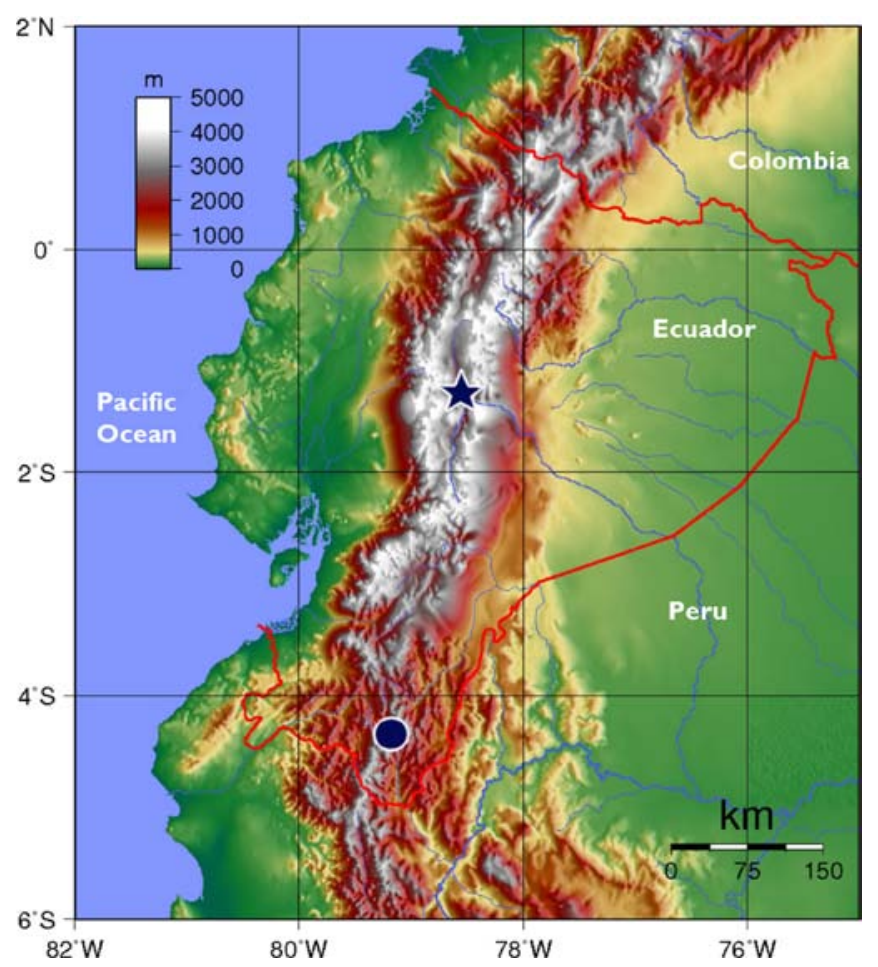

Figure 6. Map of distribution of the two new species. Star, type locality of Vercammenia neotropica n. sp.; circle, type locality of Microtrombicula ecuadorensis $\mathrm{n}$. sp.

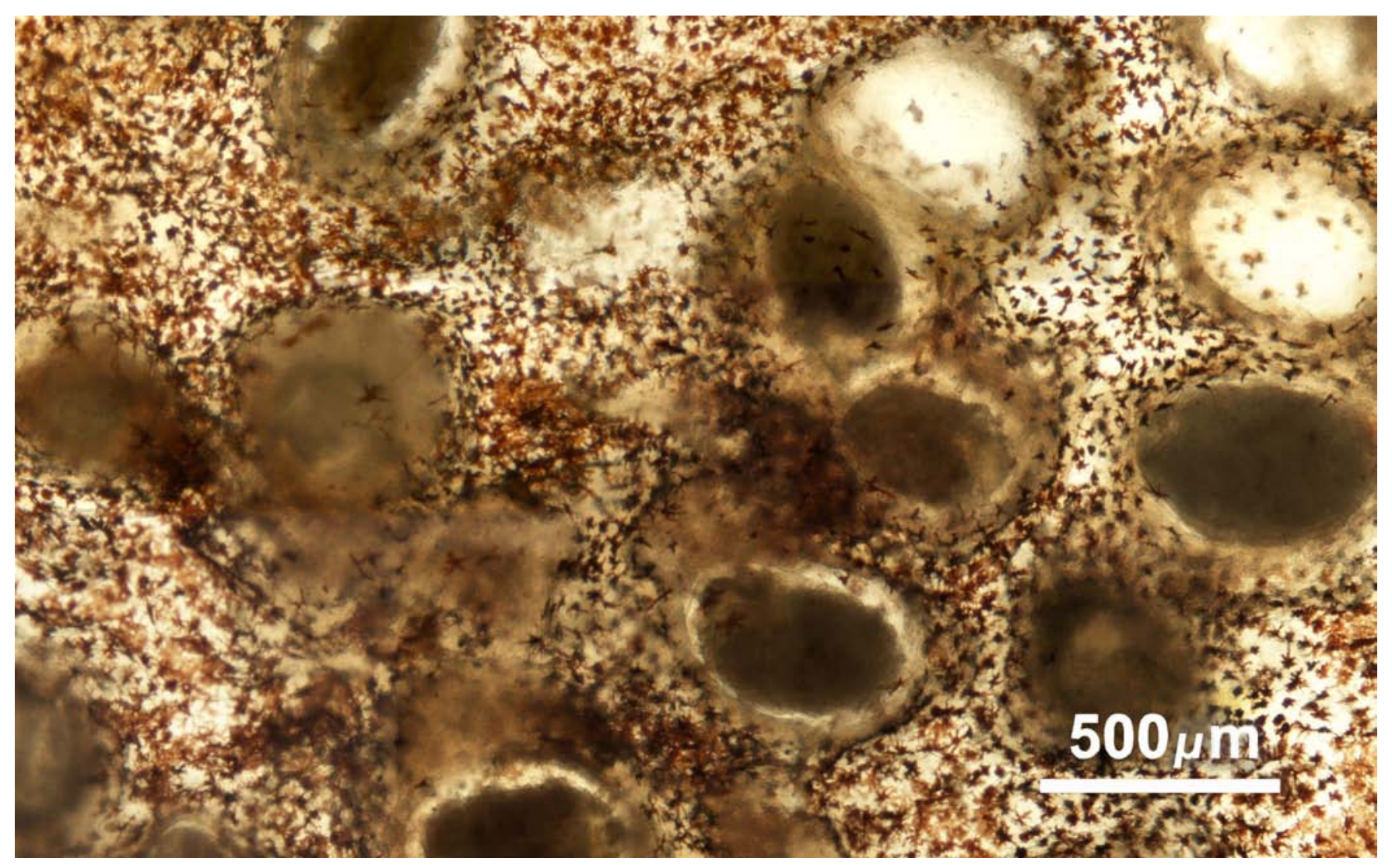

Figure 5. Microscopical view of exemplars of Vercammenia neotropica inside the skin of host. 
with a nonreticulate scutum and branched sensilla with Trombicula crossleyi Loomis 1954 as the type species, later the same author (Vercammen-Grandjean, 1965) included 12 species with palpal claw bifurcate and 3 genualae I. Webb and Loomis (1971) in their diagnosis of Scapuscutala included the American species that are characterized by the following: "having pretarsala II, 3 genualae I, 3 pairs of sternal setae and/or coxa III multiple setae, palpal claw bifurcate, $\mathrm{PL} \geq A \mathrm{~L}$, scutum with small scattered puncta, and sensillae flagelliform with basal barbs and 8-16 distal branches." Hoffmann (1990) points out that these characters are variable among species, and she does not accept the subgenus designation; here, we follow her point of view but refer to "Scapuscutala" as a species group with 6B or $6 B \& N$ on palpal tarsus, palpal claw bifurcate, 3 genualae I, scutum with puncta and sensilla with 8-16 distal branched as the exemplars described here. The species with these characters are: Microtrombicula crossleyi (Loomis, 1954), $M$.

Table 3. Microtrombicula ecuadorensis $\mathrm{n}$. sp. measurements of scutal setae of the type-series

\begin{tabular}{|c|c|c|c|c|c|c|c|c|c|c|c|}
\hline & AW & PW & SB & ASB & PSB & SD & AP & AM & $\mathrm{AL}$ & $\mathrm{PL}$ & $S$ \\
\hline Holotype & 56 & 66 & 21 & 29 & 27 & 56 & 26 & 30 & 29 & 42 & 61 \\
\hline Minimum & 47 & 60 & 18 & 29 & 26 & 56 & 26 & 29 & 26 & 39 & 50 \\
\hline Maximum & 63 & 74 & 24 & 37 & 32 & 70 & 32 & 34 & 30 & 45 & 61 \\
\hline Mean & 54 & 65 & 20 & 32 & 28 & 60 & 28 & 32 & 28 & 42 & 58 \\
\hline St. Dev. & 3.5 & 3.5 & 1.6 & 2.7 & 1.7 & 4.2 & 1.6 & 1.7 & 1.3 & 1.8 & 4.0 \\
\hline
\end{tabular}

Abbreviations: $A W=$ distance between ALs; PW = distance between PLs; SB = distance between sensillary bases; $A S B=$ distance from level of sensillary bases to extreme anterior margin of scutum; $P S B=$ distance from level of sensillary bases to extreme posterior margin of scutum; $S D=$ length of scutum (ASB + PSB); $A P$ = distance from $A L$ to $P L$ on one side; $A M=$ length of tanteromedian setae; $A L=$ length of anterolateral setae; $\mathrm{PL}=$ length of posterolateral setae; $\mathrm{S}=$ length of sensilla.

$(n=17)$

Table 4. Microtrombicula ecuadorensis n. sp. measurements of the modified setae of legs in the type-series

$\begin{array}{llllllllllll}\text { Tarsus } & & & \text { Tibia } & & \text { Genu } & & \\ & \text { pret } & \text { subt } & \text { paras mcta } & \text { tib } \varphi \quad \text { tib } & \text { mcti } & \text { ge1 } & \text { ge2 } & \text { ge3 } & \text { mcg }\end{array}$

\begin{tabular}{lcccccccccccc}
\hline Leg I & & & & & & & & & & & & \\
Holotype & 34 & 13 & 26 & 7.5 & 4.2 & 20 & 22 & 4.3 & 21 & 23 & 23 & 3.3 \\
Minimum & 31 & 11 & 226 & 5.3 & 2.9 & 17 & 20 & 2.8 & 17 & 19 & 21 & 2.6 \\
Maximum & 36 & 14 & 30 & 9.8 & 4.2 & 21 & 25 & 4.6 & 24 & 24 & 24 & 4.1 \\
Mean & 34 & 13 & 28 & 7.0 & 3.4 & 19 & 23 & 3.7 & 21 & 22 & 22. & 3.3 \\
St. Dev. & 1.4 & 0.9 & 1.3 & 1.2 & 0.3 & 1.1 & 1.3 & 0.5 & 1.9 & 1.5 & 1.1 & 0.6
\end{tabular}

Leg II

$\begin{array}{lllllll}\text { Holotype } & 18 & 12 & 2.8 & 20 & 20 & 23 \\ \text { Minimum } & 17 & 9.4 & 2.4 & 16 & 16 & 18 \\ \text { Maximum } & 20 & 14 & 4.3 & 21 & 23 & 23 \\ \text { Mean } & 18 & 12 & 3.2 & 19 & 20 & 21 \\ \text { St. Dev. } & 0.9 & 1.5 & 1.5 & 1.4 & 1.7 & 1.9\end{array}$

$\begin{array}{lccc}\text { Leg III } & \text { Mtar } & & \\ \text { Holotype } & 39 & 21 & 23 \\ \text { Minimum } & 31 & 19 & 20 \\ \text { Maximum } & 42 & 23 & 24 \\ \text { Mean } & 37 & 21 & 22 \\ \text { St. Dev. } & 3.1 & 1.0 & 1.2\end{array}$

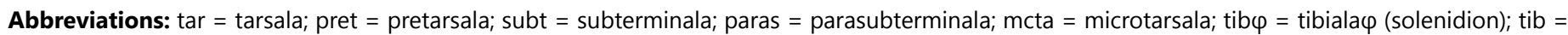
tibiala; $\mathrm{mcti}=$ microtibiala; ge1 = genuala $1 ;$ ge $2=$ genuala $2 ;$ ge $3=$ genuala $3 ;$ mcg $=$ microgenuala; Mtar $=$ mastitarsala.

$(n=16)$ 
rhoptropi (Lawrence, 1949), M. trisetica (Loomis and Crossley, 1953), M. maura (Taufflieb, 1960), M. meridialis (Taufflieb, 1960), M. nadchatrami Vercammen-Grandjean, 1965 , M. nicaraguae Webb and Loomis, 1970, M. paralios Webb and Loomis, 1970, M. aequalis Webb and Loomis, 1971, M. fisheri Webb and Loomis, 1971, M. intermedia Webb and Loomis, 1971, and M. mesoamericana Webb and Loomis, 1971. Microtrombicula trisetica, M. aequalis, M. crossley, M. fischeri, and $M$. intermedia have coxa III multisetose, the $\mathrm{fCx}$ in M. ecuadorensis n. sp. is 1-1-1; in M. maura, M. meridialis, and $M$. mesoamericana there are 6 sternal setae, in $M$. ecuadorensis only 4; M. nadchatrami, M. paralios, and M. nicaraguae have NDV $=70-72$, but $M$. ecuadorensis has fewer setae (NDV = 44), thus M. rhoptropi is the more similar, but in this species the palpal tarsus is $6 \mathrm{~B}, \mathrm{fPp} B / \mathrm{N} / \mathrm{N} . N . N$ and $f C x$ B.B.B, in M. ecuadorensis $2 N 4 B, f P p B / B / B N B$, and $f C x$ B.N.B, respectively.

A total of 19 specimens of Pristimantis aff. bellator from the Tapichalaca biological reserve were collected in the years 2003, 2008, and 2012; 32\% (6) of the specimens examined of these terrestrial frogs were infected in 2008 and 2012, Microtrombicula ecuadorensis was found in two red cavities under the skin on each side of the axial region and flanks. All terrestrial frogs that were found infected were collected on the ground among moss or leaf litter.

\section{Discussion}

Species that can be allocated to 3 genera have been described from subcutaneous tissues in anurans; these are: Hannemania Oudemans, 1911 in the New World and New Caledonia; Endotrombicula Ewing, 1931 in Africa; and Vercammenia Audy and Nadchatram, 1957 in Southeast Asia and Australia. In the western hemisphere, 25 species of Hannemania have been reported (Wohltmann et al. 2006, Silva de la Fuente et al., 2016), and two other species are of uncertain status, Trombicula yorkei Sambon, 1928 in Brazil and Schoengastia lynni Ewing, 1942 in Jamaica. T. yorkei was described by Sambon (1928) with "found in tiny whitish cyst on the inter-digital web of the feet of Hyla rubra" and characterized by the "shape of the dorsal shield," but the species was very incompletely described. Later Domrow (1969) in his review of Vercammenia redescribed the species on the basis of the holotype and three topotypes and renamed it Vercammenia yorkei (Sambon, 1928), but he does not provide justification to place these exemplars in the genus Vercammenia; in his description the species has a palpal tarsus $6 \mathrm{~B}$, palpal claw with two prongs, eyes $1+1$, and in figure 17 a mastitarsala is very clear in leg III as well as in the pretarsala II-in fact, all these characters are present in Microtrombicula. Therefore, $T$. yorkei must be transferred to this genus as Microtrombicula yorkei (Sambon, 1928) n. comb.

Schoengastia lynni Ewing, 1942 was also briefly described from exemplars without sensilla. Wharton and Fuller (1952) proposed a new combination as Endotrombicula lynni without any comment, but the original description is poor with no mention of them being endoparasitic. Therefore, Domrow (1969) excluded this species from consideration, and he agreed with Wohltmann et al. (2007). However, the types are lost, and we feel that this species should be considered incertae sedis until more material can be collected.

Acknowledgments - Specimens of Pristimantis were collected through the funding of projects supported by the Fundación Jocotoco, Fundación Ecominga, and the "Programade Becas de Investigación para la Conservación Fernando Ortíz" of Ecociencia. Research permits were provided by the Ministerio del Ambiente No. 018-IC-FAU-DNBAP/MA, No. 010 ICFAUDNBAPVS/MA, and No. MAE-DPZCH,2012-0626. We heartily thank Carolina Reyes-Puig for facilitating our examination of specimens in the INABIO collections and for providing valuable comments and suggestions in the development of this manuscript. Thanks also go to Barbara de Guerrero for providing final assistance with artwork and to Scott Lyell Gardner, Manter Laboratory of Parasitology, for review of the English language.

\section{References}

Audy, J. R.; and Nadchatram, M. 1957. Malaysian Parasites. XIX. Vercammenia, new genus of chiggers hypodermal in Amphibia (Acarina, Trombiculidae). Studies from the Institute for Medical Research Federation of Malaya, 28: 95-102.

Brennan, J. M.; and Yunker, C. E. 1966. Endoparasitic chiggers. III. Euschoengastia velata n. sp. (Acarina), an intradermal parasite of boreal rodents in Montana. Journal of Medical Entomology, 3: 338-339.

Brennan, J. M.; and Yunker, C. E. 1969. Endoparasitic chiggers: V. New genera, species and records from Venezuela and Brazil (Acarina: Trombiculidae). Journal of Medical Entomology, 6: 299-304.

Domrow, R. 1969. The Genus Vercammenia Audy and Nadchatram (Acari: Trombiculidae). Journal of Australian Entomological Society, 8: 161-167.

Domrow, R.; and Lester, L. N. 1985. Chiggers of Australia (Acari: Trombiculidae): An Annotated Checklist and Bibliography. Australian Journal of Zoology, Supplementary Series, 114: 1-111.

Domrow, R.; Loomis, R. B.; and Lester, L. N. 1983. The Genus Vercammenia Audy and Nadchatram in Australian frogs (Acari: Trombiculidae). Journal of Australian Entomological Society, 22: 205-209. 
Ewing, H. E. 1942. Remarks on the Taxonomy of some American chiggers (Trombiculinae), including the description of new genera and species. Journal of Parasitology, 28: 485-491.

Ewing, H. E. 1950. A redescription of four genera of chigger mites, together with a description of a new genus and subgenus. Proceedings of the Entomological Society of Washington, 52: 291-299.

Fernandes, S. J.; and Kulkarni, S. M. 2003. Studies on the trombiculid mite fauna of India. Record of the Zoological Survey in India, Occasional Paper, 212: 1-539.

Gazêta, G. S., Amorim, M.; Bossi, D.; Linhares, A.; and SerraFreire, N. M. 2006. Caamembecaia gratiosus n. gen., n. sp. (Acari: Trombiculidae), from Trinomys gratiosus (Gunter) (Rodentia: Echimydae), of Atlantic Forest in Southeastern Brazil. Memorias do Instituto Oswaldo Cruz, 101: 137-139.

Goff, M. L.; Loomis, R. B.; Welbourn, W. C.; and Wrenn, W. J. 1982. A glossary of chigger terminology (Acari: Trombiculidae). Journal of Medical Entomology, 19: 221-238.

Hoffmann, A. 1990. Los trombiculidos de México (Acarina: Trombiculidae). Parte Taxonómica. Publicaciones Especiales 2, Universidad Nacional Autónoma de México, México, p. 275.

Krantz, G. W.; and Walter, D. E. 2009. A Manual of Acarology. 3rd edition. Texas Tech University Press, Lubbock. viii +807 pp.

Nadchatram, M. 2006. A review of endoparasitic acarines of Malaysia with special reference to novel endoparasitism of mites in amphibious sea snakes and supplementary notes on ecology of chiggers. Tropical Biomedicine, 23: 1-22.

Reyes-Puig, J. P.; Reyes-Puig, C.; Ramírez, J. S.; Pérez-Lara, M.; and Yánez-Muñoz, M. H. 2010. Tres nuevas especies de ranas terrestres Pristimantis de la cuenca alta del Río Pastaza. Avances en Ciencias e Ingenieria, 6: B51-B62.

Sambon, L. W. 1928. The parasitic Acariens of animals and the part they play in the causation of the eruptive fevers and other diseases of man. Annals of Tropical Medicine and Parasitology, 22: 67-132.

Silva de la Fuente, M. C.; Moreno-Salas, L.; and Castro-Carrasco, C. 2016. Review of the genus Hannemania (Acari: Leeuwenhoekiidae) with description the two new species in amphibians from Chile. Zootaxa, 4200: 580-590.

Stekolnikov, A. A.; and Daniel, M. 2012. Chigger mites (Acari: Trombiculidae) of Turkey. Zootaxa, 3216: 1-104.

Stekolnikov, A. A.; and González-Acuña, D. 2015. A review of Chilean chiggers (Acari: Trombiculidae), with the description of a new genus and ten new species. Zootaxa, 3964: $1-43$.
Vercammen-Grandjean, P. H. 1960. Introduction á un Essai de Classification Rationnelle des larves de Trombiculinae Ewing 1944 (Acarina-Trombiculidae). Acarologia, 2: 469$471+1$ unpaginated table.

Vercammen-Grandjean, P. H. 1965. Revision of the genera: Eltonella Audy, 1956 and Microtrombicula Ewing, 1950 with descriptions of fifty new species and transferal of subgenus Chiroptella to genus Leptotrombidium (Acarina: Trombiculidae). Acarologia, 7 fascule supplementaire: 34-257.

Vercammen-Grandjean, P. H.; and Benoit, P. L. G. 1971. Un aoutat Africain parasite d'une limace. Revue de Zoologie et Botanique Africaine, 83: 180-187.

Webb, J. P.; and Loomis, R. B. 1970. A new subgenus of intranasal chiggers of the genus Microtrombicula from North America and Korea. Journal of Medical Entomology, 7: 655-663.

Webb, J. P.; and Loomis, R. B. 1971. The subgenus Scapuscutala of the Genus Microtrombicula (Acarina: Trombiculidae) from North America. Journal of Medical Entomology, 8: 319-329.

Wharton, G. W.; and Fuller, H. S. 1952. A manual of the chiggers. Memoirs of the Entomological Society of Washington, 4: 1-185.

Wohltmann, A.; Köhler, J.; and Martin, P. 2006. Endoparasitic mite infections of anuran amphibians from Bolivian montane rain forests, with descriptions of two new Hannemania species (Acari: Parasitengona: Trombiculidae: Leeuwenhoekiinae). Organisms, Diversity and Evolution, 6: 141-150.

Wohltmann, A.; du Preez, L.; Rödel, M.-O.; Köhler, J.; and Vences, M. 2007. Endoparasitic mites of the genus Endotrombicula Ewing, 1931 (Acari: Prostigmata: Parasitengona: Trombiculidae) from African and Madagascan anurans, with description of a new species. Folia Parasitologica, 54: 225-235.

Yánez-Muñoz, M. H.; Meza-Ramos, P. A.; Ramírez-Jaramillo, S. M.; and Morales, M. 2013. Reserva Biológica Tapichalaca: Un epicentro de biodiversidad en las laderas orientales de los Andes sur de Ecuador. In Mecn, Jocotoco y Ecominga. 2013. Herpetofauna en Áreas Prioritarias para la Conservación: El sistema de Reservas Jocotoco y Ecominga. Monografía 6: 1-392. Serie de Publicaciones del Museo Ecuatoriano de Ciencias Naturales (MECN), Fundación para la Conservación Jocotoco, Fundación Ecominga, Quito. 184$194 \mathrm{p}$.

Yunker, C. E.; and Jones, E. K. 1961. Chiroptera, a new host order for intranasal chiggers, with descriptions of two new genera and species (Acarina: Trombiculidae). Journal of Parasitology, 47: 995-1000. 